\title{
Divergence of the fermentative and bromatological characteristics of 25 sorghum hybrid silages ${ }^{1}$
}

\section{Thiago Carvalho da Silva ${ }^{2}$, Edson Mauro Santos ${ }^{3}$, Carlos Henrique Oliveira Macedo ${ }^{3}$, Milena Araújo de Lima ${ }^{4}$, Higor Fábio Carvalho Bezerra ${ }^{3}$, José Augusto Gomes Azevêdo ${ }^{4}$, José Avelino Santos Rodrigues ${ }^{5}$, Juliana Silva de Oliveira ${ }^{3}$}

\footnotetext{
1 Financed by Conselho Nacional de Desenvolvimento Científico e Tecnológico (CNPq).

2 Departamento de Zootecnia, Universidade Federal de Viçosa, Viçosa, MG, Brasil, 36570-000.

${ }^{3}$ Departamento de Zootecnia, Centro de Ciências Agrárias, Universidade Federal da Paraíba, Campus II, Areia, PB, Brasil.

${ }^{4}$ Departamento de Ciências Agrárias e Ambientais, Universidade Estadual de Santa Cruz, Ilhéus, BA, Brasil.

${ }^{5}$ Centro Nacional de Pesquisa em Milho e Sorgo, Embrapa Milho e Sorgo, Sete Lagoas, MG, Brasil.
}

\begin{abstract}
The objective of this study was to evaluate the divergence of bromatological and fermentative characteristics of silages of 25 sorghum (Sorghum bicolor L. Moench) hybrids. The experimental design was completely randomized with 25 treatments and four replications. The mean values of $\mathrm{pH}$ differed with variation from 3.45 to 3.87 for hybrids 866005 and 870051, respectively, and the mean pH value was 3.66. The average percentage of lactic acid ranged from 2.90 to $7.43 \mathrm{dag} / \mathrm{kg}$ of dry matter (DM) in hybrids 870035 and 866005, respectively, with an average of $4.65 \mathrm{dag} / \mathrm{kg} \mathrm{DM}$. Through cluster analysis by the Tocher method and average Euclidean distance based on the fermentative characteristics, five groups were formed: one with 18 hybrids, another with four and three groups with one hybrid in each. In group three, there were the hybrids that showed the highest values of lactic acid. Hybrids 870025, 870035, 870081, 870095, 866034, and 870031 showed higher DM content and the hybrid BRS 610 had the lowest average compared with the others. Hybrids 1F305, BRS 610, Volumax, and XBS60329 had the lowest levels of non-fiber carbohydrates and higher neutral detergent fiber corrected for ash and protein. Despite the fermentative and bromatological divergences between hybrids, they are not a limiting factor to silage production.
\end{abstract}

Key Words: crude protein, forage conservation, non-fiber carbohydrates, semiarid

\section{Introduction}

The semiarid northeastern region of Brazil is characterized by having unevenly distributed rainfall, concentrated in a short rainy season, followed by a long dry season. This irregular pattern of rainfall is one of the biggest challenges in producing feed for livestock.

The forage conservation in the form of silage can be a viable alternative to reduce the problem of scarcity of forage in drier times of the year and enable the production systems in the semiarid region.

Among the various grass species that have characteristics for silage, corn (Zea mays) and sorghum (Sorghum bicolor L. Moench) are those with the most appropriate profile for this purpose due to the ease of cultivation, high forage yield, and especially, the characteristics that promote silage of adequate fermentation and satisfactory quality, as the high content of soluble carbohydrates. In the evaluation of sorghum hybrids, producers seek for the combination of production traits and high nutritional value, and to meet the nutritional requirements, reduce the cost with feeding and contribute to optimum bioeconomic performance.

Currently, there is the market availability of hybrids that have good balance of stalks, leaves and panicles, combining high dry matter (DM) productivity and high nutritional value (Molina et al., 2002). The sorghum forage is characterized by high natural matter (NM) production per hectare, with a lower number of panicles. The dual-purpose sorghum has high yields of NM and DM combined with greater participation of the panicle component, reaching $68 \%$ in DM (Silva et al., 2011).

Sorghum silages are characterized for presenting appropriate fermentation profile, given the amount of soluble carbohydrates mainly present in the stem, which ensure the preservation of the fermentation and nutritive value of the ensiled material. Ribeiro et al. (2007), evaluating sorghum hybrids, observed proper fermentation profile of the silage in terms of DM content, crude protein, ammonia nitrogen in relation to total nitrogen and $\mathrm{pH}$, with values of 32.65, 6.82, 1.92 and 4.02, respectively. The nutritional 
value of sorghum silage depends on the characteristics of the hybrid used, such as height, percentage of panicles, stem and leaf, and the stage of maturity at harvest (Cândido et al., 2002).

Therefore, the objective was to evaluate the divergences of bromatological and fermentation characteristics of the silages of 25 sorghum hybrids.

\section{Material and Methods}

Twenty-five sorghum hybrids (Sorghum bicolor L. Moench) developed by the breeding program of Embrapa Milho e Sorgo designated by the following names or codes were evaluated: 866005, 866019, 866033, 866034, 866035, 866036, 866037, 866040, 866041, 866042, 866043, 866044, 870025, 870031, 870035, 870041, 870051, 870067, 870081, 870085, 870095, 1F305, BRS 610, Volumax and XBS60329.

The hybrids were grown at the experimental station of the Instituto Nacional do Semi-Árido (INSA), in Campina Grande, Paraíba, Brazil.

Sowing took place on April 18, 2009, in plots of $4.9 \mathrm{~m}^{2}$ $(4.9 \times 1.0 \mathrm{~m})$, spaced $70 \mathrm{~cm}$ between rows and thirty days after planting, thinning was performed in order to keep the crop density of 12 plants per linear meter. Fertilization based on soil chemical properties of the experimental area was conducted, using $100 \mathrm{~kg} / \mathrm{ha}$ of nitrogen in the form of ammonium sulfate and $60 \mathrm{~kg} / \mathrm{ha}$ of $\mathrm{P}_{2} \mathrm{O}_{5}$ in the form of superphosphate. The application of nitrogen was split, with 50\% applied in the thinning period and the remaining fifteen days after thinning, while the phosphorus was applied at planting.

The hybrids were harvested and ensiled at the dough stage. As experimental hybrids reached the point of harvest on different days, three harvests were conducted. At 98 days, hybrids 866042, 866043, 866044, 870025, 870035, 870041, 870051, 870067, and BRS 610 were harvested. Hybrids 866005, 866019, 866033, 866034, 866035, 866036, 866037, 866040, 866041, 870031, 870081, 870085, 870095, Volumax, and XBS60329 were harvested at 104 days, and hybrid 1F305, at 131 days.

The plants were cut with knives $10 \mathrm{~cm}$ away from the soil and then chopped in a stationary forage machine. The material was ensiled in PVC silos with $10 \mathrm{~cm}$ of diameter and $40 \mathrm{~cm}$ of height. The compaction of the material was performed with wooden sockets to reach a density of about $550 \mathrm{~kg} / \mathrm{m}^{3}$. The silos were opened 40 days after ensiling.

The experiment was conducted in February 2010, at the Laboratory of Animal Nutrition of the Center of Agrarian Sciences of Universidade Federal da Paraíba (UFPB), located in Areia, Paraíba, Brazil, and at the Laboratory of Animal
Nutrition of Universidade Estadual de Santa Cruz, belonging to the municipality Ilheus, Bahia, Brazil.

The design was completely randomized with 25 treatments and four replications; the silages of 25 sorghum hybrids were the treatments evaluated.

For $\mathrm{pH}$ determination, samples of approximately $25 \mathrm{~g}$ of silage were collected, to which $100 \mathrm{~mL}$ of water were added, and, after resting for an hour, the reading of the $\mathrm{pH}$ was performed, using a potentiometer. In another sample of $25 \mathrm{~g}, 200 \mathrm{~mL}$ of a $0.2 \mathrm{~N} \mathrm{H}_{2} \mathrm{SO}_{4}$ solution were added to remain at rest for 48 hours, for filtering on Whatman filter to be performed. This filtrated solution was stored in the refrigerator for further analysis of ammonia-N (Bolsen et al., 1992). For the analysis of organic acids, $10 \mathrm{~g}$ of sample were dissolved into $90 \mathrm{~mL}$ of distilled water and filtered through Whatman-type filter paper (Kung Jr. \& Ranjit, 2001). $1 \mathrm{~mL}$ of $20 \%$ metaphosphoric acid solution was added to $2 \mathrm{~mL}$ of filtrate. The samples were centrifuged at $13,000 \mathrm{rpm}$ for 15 minutes, and then submitted to analysis of organic acids (lactic, acetic, propionic and butyric acids) in SHIMADZU high performance liquid chromatography (HPLC) coupled to a UV detector (UV), model SPD-10A VP using $210 \mathrm{~nm}$ as wavelength.

Approximately $500 \mathrm{~g}$ of silage sample were collected from each silo. These samples were oven-dried $\left(60 \pm 5^{\circ} \mathrm{C}\right)$ for $72 \mathrm{~h}$, and processed in a knife mill with $1 \mathrm{~mm}$ sieve. From these samples, the dry matter (DM), crude protein (CP), mineral matter(MM) and ether extract(EE) were determined, according to methods described by Silva \& Queiroz (2002). The contents of neutral detergent fiber (NDF) and acid detergent fiber (ADF) were evaluated using the compositions of detergent recommended by Mertens (2002) and Goering \& Van Soest (1975), respectively. The autoclave micro-extraction method was used (Pell \& Schofield, 1993). In the NDF analysis, the samples were treated with thermo-stable alpha-amylase, without the use of sodium sulfite and corrected for residual ash. The correction for ash from NDF and estimation contents of neutral detergent insoluble nitrogen (NDIN) and acid detergent insoluble nitrogen (ADIN) were made according to Licitra et al. (1996). The content of hemicellulose (HEM) was calculated by subtracting the NDF corrected for ash and protein (NDFcp) by the ADF corrected for protein (ADFp).

The concentration of non-fibrous carbohydrates (NFC) was estimated through the following formula: $\% \mathrm{NFC}=100$ - (\%CP + NDFap\% + \%EE + \%MM), in which NDFap ccorresponds to NDF corrected for ash and protein (Sniffen et al., 1992).

The results were subjected to analysis of variance and when necessary, the Scott-Knott test $(\alpha=0.05)$ was used to compare the means of each hybrid, using the software 
SAEG (Sistema deAnálises Estatísticas e Genéticas, version 8.0). The test proposed by Scott \& Knott (1974) was used for being a clustering method that, unlike other univariate tests of multiple comparison of means, eliminates the ambiguity and separates the means of treatments into homogeneous groups, facilitating the interpretation, especially when working with a large number of treatments (Santos et al., 2001).

Multivariate analysis was performed using as an aid tool the software SAEG (Sistema de Análises Estatísticas e Genéticas, version 8.0). The fermentation characteristics were examined by hierarchical clustering analysis using the Tocher method (Johnson \& Wichern, 1992), adopting the Euclidean mean distance as a basic measure of dissimilarity and standardized data. $\mathrm{pH}, \mathrm{N}-\mathrm{NH}_{3}$, and organic acids (latic, acetic, propionic and butyric) were used as discriminatory features.

\section{Results and Discussion}

According to the statistical analysis, difference $(\mathrm{P}<0.05)$ between the ensiled hybrids was observed for all fermentation characteristics evaluated (Table 1).

The average $\mathrm{pH}$ values were higher $(\mathrm{P}<0.05)$ for the silage made with hybrids 870025, 870031, 870041, 870067,
870051870085 and 870081 , with values greater than 3.75, followed by hybrids 866037, 866040, 866042, XBS60329, 870035, 866044, which had $\mathrm{pH}$ values of silages varying between 3.79 and 3.81. According to McDonald et al. (1991), the optimal $\mathrm{pH}$ for well preserved silage should be between 3.8 and 4.2 .

The silage made of hybrids 866036, 866035, 870095, Volumax, 866034, 866043, 1F305 and 866041 presented average $\mathrm{pH}$ between 3.72 and 3.67. These values were higher $(\mathrm{P}<0.05)$ in comparison with hybrids 866005 , 866033, 866019, and BRS 610, which showed values inferior to 3.56, with a minimum of 3.45 for hybrid 866005. The low $\mathrm{pH}$ of these silages may be due to the soluble carbohydrates content of plants at the time of ensiling, because these are the main substrate used by lactic acid bacteria, contributing to acidification, due to the increase in lactic acid production, with low negative correlation, which in this study was -0.57 .

The production of $\mathrm{N}-\mathrm{NH}_{3}$ was higher $(\mathrm{P}<0.05)$ for hybrids 866033, BRS610, and 1F305, with values between 5.64 and $6.81 \mathrm{dag} / \mathrm{kg}$ of total nitrogen (Table 1 ). According to Molina et al. (2002), silages which have $\mathrm{N}-\mathrm{NH}_{3}$ values lower than $12 \mathrm{dag} / \mathrm{kg}$ total nitrogen are considered of good quality. Therefore, the results found in this study were

Table 1 - Mean values of the silage fermentation characteristics of 25 sorghum hybrids

\begin{tabular}{|c|c|c|c|c|c|c|}
\hline \multirow[t]{2}{*}{ Hybrid } & \multirow[t]{2}{*}{$\mathrm{pH}$} & \multirow{2}{*}{$\frac{\mathrm{N}-\mathrm{NH}_{3}}{\mathrm{dag} / \mathrm{kg} \mathrm{TN}}$} & LA & AA & P A & BA \\
\hline & & & \multicolumn{4}{|c|}{ dag/kg DM } \\
\hline 866005 & $3.45 \mathrm{~d}^{*}$ & $4.58 b$ & $7.43 a$ & $0.85 b$ & $0.29 a$ & $0.04 \mathrm{a}$ \\
\hline 866019 & 3.53d & $4.69 b$ & $5.92 c$ & $1.04 \mathrm{a}$ & $0.23 b$ & $0.04 \mathrm{a}$ \\
\hline 866033 & $3.49 \mathrm{~d}$ & $5.69 a$ & $4.45 d$ & $1.01 \mathrm{a}$ & $0.22 b$ & $0.02 b$ \\
\hline 866034 & $3.59 c$ & $4.85 b$ & $4.30 \mathrm{~d}$ & $0.90 \mathrm{~b}$ & $0.18 b$ & $0.02 b$ \\
\hline 866035 & $3.56 c$ & $4.13 c$ & $4.65 d$ & $1.02 \mathrm{a}$ & $0.22 b$ & $0.03 \mathrm{~b}$ \\
\hline 866036 & $3.56 c$ & $2.86 \mathrm{c}$ & $5.53 c$ & $1.03 a$ & $0.23 b$ & $0.02 b$ \\
\hline 866037 & $3.67 b$ & $4.18 c$ & $5.17 d$ & $0.92 b$ & $0.21 b$ & $0.02 b$ \\
\hline 866040 & $3.67 b$ & $2.90 c$ & $4.57 d$ & $0.94 b$ & $0.21 b$ & $0.02 b$ \\
\hline 866041 & $3.65 c$ & $3.17 \mathrm{C}$ & $4.84 d$ & $0.97 a$ & $0.24 b$ & $0.02 b$ \\
\hline 866042 & $3.68 \mathrm{~b}$ & $3.54 c$ & $4.74 d$ & $0.65 c$ & $0.27 \mathrm{a}$ & $0.04 \mathrm{a}$ \\
\hline 866043 & $3.60 \mathrm{c}$ & $3.18 c$ & $5.47 \mathrm{c}$ & $0.71 \mathrm{c}$ & $0.29 a$ & $0.03 \mathrm{~b}$ \\
\hline 866044 & $3.72 b$ & $4.09 c$ & $5.27 \mathrm{c}$ & $0.61 \mathrm{c}$ & $0.27 a$ & $0.04 \mathrm{a}$ \\
\hline 870025 & $3.76 a$ & $3.45 c$ & $4.04 d$ & $0.52 d$ & $0.21 b$ & $0.03 \mathrm{~b}$ \\
\hline 870031 & $3.77 a$ & $3.57 c$ & $3.97 \mathrm{e}$ & $0.47 \mathrm{~d}$ & $0.20 \mathrm{~b}$ & $0.03 \mathrm{~b}$ \\
\hline 870035 & $3.71 b$ & $3.01 \mathrm{c}$ & $2.90 \mathrm{f}$ & $0.26 \mathrm{e}$ & $0.23 b$ & $0.02 \mathrm{~b}$ \\
\hline 870041 & $3.79 a$ & $3.70 \mathrm{c}$ & $4.36 \mathrm{~d}$ & $0.58 c$ & $0.22 b$ & $0.03 b$ \\
\hline 870051 & $3.87 a$ & $4.51 b$ & $3.78 \mathrm{e}$ & $0.62 \mathrm{c}$ & $0.24 b$ & $0.04 \mathrm{a}$ \\
\hline 870067 & $3.80 \mathrm{a}$ & $3.84 \mathrm{c}$ & 4.61d & $0.70 \mathrm{c}$ & $0.22 b$ & $0.04 \mathrm{a}$ \\
\hline 870081 & 3.83a & $3.46 c$ & $3.34 \mathrm{f}$ & $0.51 d$ & $0.20 \mathrm{~b}$ & $0.02 b$ \\
\hline 870085 & $3.81 \mathrm{a}$ & $2.98 c$ & $3.90 \mathrm{e}$ & $0.54 d$ & $0.18 b$ & $0.02 b$ \\
\hline 870095 & $3.57 c$ & $4.22 \mathrm{c}$ & $4.29 \mathrm{~d}$ & $0.53 d$ & $0.17 \mathrm{~b}$ & $0.02 b$ \\
\hline 1F305 & $3.63 c$ & $6.81 \mathrm{a}$ & $4.49 d$ & $0.71 \mathrm{c}$ & $0.29 a$ & $0.04 \mathrm{a}$ \\
\hline BRS 610 & $3.54 d$ & $5.64 a$ & $6.43 b$ & $0.91 b$ & $0.34 a$ & $0.04 \mathrm{a}$ \\
\hline Volumax & $3.57 c$ & $5.05 b$ & $4.56 \mathrm{~d}$ & $0.84 b$ & $0.30 a$ & $0.03 b$ \\
\hline XBS60329 & $3.68 d$ & $4.20 c$ & $3.30 \mathrm{f}$ & $0.64 c$ & $0.18 b$ & $0.02 b$ \\
\hline Mean & 3.66 & 4.09 & 4.65 & 0.74 & 0.23 & 0.03 \\
\hline CV (\%) & 1.31 & 21.81 & 8.34 & 12.81 & 17.63 & 26.38 \\
\hline
\end{tabular}

$\mathrm{N}-\mathrm{NH}_{3}$ - ammonia nitrogen; LA - lactic acid; AA - acetic acid; PA - propionic acid; BA - butyric acid; TN - total nitrogen; DM - dry matter; CV - coefficient of variation. * Means followed by same letter in the column do not differ by the Scott-Knott test $(\alpha=0.05)$. 
lower than those in the literature (Araujo et al., 2007; Ribeiro et al., 2007), which may be associated with adequate fermentation of the ensiled hybrids. The $\mathrm{N}-\mathrm{NH}_{3}$, expressed in $\mathrm{dag} / \mathrm{kg}$ of total- $\mathrm{N}$ is regarded as one of the main variables resulting from the fermentation quality because it is an indicator of proteolysis during the fermentation process, conducted mainly by bacteria called Clostridium. According to Woolford (1984) and McDonald et al. (1991), the proteolysis extends during fermentation when there is no acidic conditions sufficient for the undesirable microorganisms to be inhibited.

The average percentage of lactic acid ranged $(\mathrm{P}<0.05)$ from 2.90 to $7.43 \mathrm{dag} / \mathrm{kg}$ of dry matter (DM), with higher $(\mathrm{P}<0.05)$ value for the hybrid 866005 . Development of lactic acid bacteria in the silo depends on the presence of soluble carbohydrates. With the proper production of lactic acid and the rapid decrease in $\mathrm{pH}$, the conditions for inhibition of proteolytic activity of plant enzymes and proliferation of undesirable bacteria are established (Santos et al., 2008).

For acetic acid, variation was observed $(\mathrm{P}<0.05)$ between hybrids with average percentage from $0.47 \mathrm{dag} / \mathrm{kg}$ DM for the hybrid 870031 to $1.04 \mathrm{dag} / \mathrm{kg} \mathrm{DM}$, for hybrid 866019 , with an average of $0.74 \mathrm{dag} / \mathrm{kg} \mathrm{DM}$. The propionic acid showed average percentage of $0.23 \mathrm{dag} / \mathrm{kg} \mathrm{DM}$, ranging from $0.17 \%$ for hybrid 870095 to $0.34 \mathrm{dag} / \mathrm{kg} \mathrm{DM}$, for hybrid BRS610.

The high soluble carbohydrate content of sorghum silage favors the process of aerobic deterioration by fungi and yeasts, resulting in losses after the opening of the silo. However, the organic acids produced by fermentation, especially acetic and propionic acids, have fungicidal action and can mitigate this deterioration, increasing the aerobic stability of the silage (Ranjit \& Kung Jr. 2000; Kung Jr. \& Ranjit, 2001; Kleinschimit \& Kung Jr., 2006; Mendes et al., 2008). The averages of butyric acid presented difference $(\mathrm{P}<0.05)$, with values close to zero. These values confirm the absence of secondary fermentation, which could cause nutrient losses. Butyric acid production is associated with fermentations carried out by clostridial, resulting in consumption of sugars and protein, which reduces the nutritional value and also the consumption of the silage. Based on the concentrations of butyric acid, it can be inferred that the activity of proteolytic clostridia in silage of all hybrids was minimized during the fermentation process.

Based on the fermentation characteristics, it can be inferred that in all silages there was an adequate fermentation process. Even if there are significant differences between the hybrids, $\mathrm{pH}$, ammonia nitrogen and acid organic values are within the standards that characterize a well-fermented silage (McDonald et al., 1991).

Using as discriminatory features the $\mathrm{pH}, \mathrm{N}-\mathrm{NH}_{3}$, lactic, acetic, propionic and butyric acids, five groups were established, by the Tocher method: one group contained 18 hybrids, other group contained four and three groups with a hybrid each (Table 2).

Forming groups allowed the visualization of closer hybrids with one or more characteristics in common. Group 1 comprised $72 \%$ of hybrids, which had the highest average $\mathrm{pH}$ value (3.71), followed by hybrid $1 \mathrm{~F} 305$ with 3.63 . The silage hybrids with the highest concentration of lactic acid (Table 3 ) are found in group 2. These silages had the lowest average $\mathrm{pH}$, probably due to the increased amount of organic acids.

The values of ammonia nitrogen from all groups were within the range recommended by Molina et al. (2002) to obtain good quality silage, which is less than $12 \mathrm{dag} / \mathrm{kg}$ total nitrogen. However, the hybrid 1F305 (group 5) had the highest average in relation to the other groups. Even with higher $\mathrm{N}-\mathrm{NH}_{3}$ production, this did not affect the crude protein content (CP) of its silage, which was $6.79 \mathrm{dag} / \mathrm{kg} \mathrm{DM}$ (Table 4).

It is possible to infer that there was low divergence between the fermentation characteristics of the silages assessed, because the difference between the groups was low due to the similarity in the silage fermentation and these characteristics are not limiting factors to any of the hybrids tested. The values observed in this study corroborated with the literature data (Rocha Jr. et al., 2000; Cândido et al., 2002; Molina et al., 2002; Rodrigues et al., 2002; Neumann et al., 2005; Skonieski et al., 2010).

The process of silage fermentation influences directly the loss of nutrients and consequently the bromatological

Table 2 - Grouping of 25 sorghum hybrids silages, based on fermentation characteristics, using the Tocher method and the Euclidean distance

\begin{tabular}{cl}
\hline Groups & \multicolumn{1}{c}{ Hybrids } \\
\hline 1 & $866034,866035,866037,866040,866041,866042,866043,866044,870025,870031,870035,870041,870051$, \\
& $870067,870081,870085$ \\
2 & 866005, BRS 610, Volumax, 866019 \\
3 & 866033 \\
4 & 866036 \\
5 & $1 \mathrm{~F} 305$ \\
\hline
\end{tabular}


composition of the silages. As the fermentation was adequate in the silages assessed, based on the fermentation profile, no significant variation that could compromise the chemical composition of the hybrids studied was observed (Tables 4 and 5).

The DM content of silage hybrids ranged between 23.43 and $42.15 \mathrm{dag} / \mathrm{kg}$ of natural matter (NM), with an average of $34.68 \mathrm{dag} / \mathrm{kg}$ NM. Hybrids 870025, 870035,
870081, 870095, 866034, and 870031 had higher $(\mathrm{P}<0.05)$ values of DM and the hybrid BRS 610 had the lowest $(\mathrm{P}<0.05)$ average in relation to the others. The low DM content of the hybrid BRS 610 can be explained by the higher percentage of total DM in the stem, as observed by Silva et al. (2011). The higher values of DM in the silages may be associated with a high percentage of panicle, as observed by Silva et al. (2011). Neumann et al. (2002a)

Table 3 - Descriptive statistics of the fermentation characteristics of the groups formed by 25 silage sorghum hybrids

\begin{tabular}{|c|c|c|c|c|c|c|c|}
\hline \multicolumn{2}{|c|}{ Groups } & \multirow{3}{*}{$\begin{array}{c}\mathrm{pH} \\
3.71\end{array}$} & \multirow{3}{*}{$\begin{array}{c}\mathrm{N}-\mathrm{NH}_{3} \\
\mathrm{dag} / \mathrm{kg} \mathrm{TN} \\
3.72\end{array}$} & \multirow{3}{*}{$\begin{array}{l}\text { LA } \\
4.31\end{array}$} & \multirow{2}{*}{\multicolumn{2}{|c|}{$\begin{array}{l}\text { AA } \\
\text { dag/kg DM }\end{array}$}} & \multirow{3}{*}{$\begin{array}{c}\text { BA } \\
0.03\end{array}$} \\
\hline & & & & & & & \\
\hline \multirow[t]{3}{*}{1} & Mean & & & & 0.67 & 0.22 & \\
\hline & Maximum & 3.87 & 4.85 & 5.47 & 1.02 & 0.29 & 0.04 \\
\hline & CV (\%) & 2.44 & 14.77 & 15.79 & 29.39 & 14.93 & 24.23 \\
\hline \multirow[t]{2}{*}{2} & Mean & 3.52 & 4.99 & 6.08 & 0.91 & 0.29 & 0.03 \\
\hline & CV (\%) & 1.19 & 8.30 & 16.99 & 8.66 & 13.39 & 14.62 \\
\hline 3 & Mean & 3.49 & 5.69 & 4.45 & 1.01 & 0.22 & 0.02 \\
\hline 4 & Mean & 3.56 & 2.86 & 5.53 & 1.03 & 0.23 & 0.02 \\
\hline 5 & Mean & 3.63 & 6.81 & 4.49 & 0.71 & 0.29 & 0.04 \\
\hline
\end{tabular}

$\mathrm{N}-\mathrm{NH}_{3}$ - ammonia nitrogen; LA - lactic acid; AA - acetic acid; PA - propionic acid; BA - butyric acid; TN - total nitrogen; DM - dry matter; CV - coefficient of variation.

Table 4 - Bromatological composition of the silages of 25 sorghum hybrids

\begin{tabular}{|c|c|c|c|c|c|c|}
\hline \multirow[t]{2}{*}{ Hybrid } & \multirow{2}{*}{$\begin{array}{c}\text { DM } \\
\text { dag/kg NM }\end{array}$} & MM & $\mathrm{CP}$ & $\mathrm{EE}$ & NDIN & ADIN \\
\hline & & \multicolumn{3}{|c|}{ dag/kg DM } & \multicolumn{2}{|c|}{ dag/kg TN } \\
\hline 866005 & $31.74 c^{*}$ & 7.29a & $5.85 b$ & $1.73 c$ & $14.43 a$ & $9.36 \mathrm{c}$ \\
\hline 866033 & $33.36 c$ & $6.11 \mathrm{~b}$ & $6.98 a$ & $1.75 \mathrm{c}$ & $13.22 b$ & $9.76 c$ \\
\hline 866034 & $41.55 a$ & $5.68 b$ & $7.01 \mathrm{a}$ & $2.65 b$ & $14.78 \mathrm{a}$ & $11.75 b$ \\
\hline 866035 & $36.60 \mathrm{~b}$ & $6.25 b$ & $6.92 \mathrm{a}$ & $2.65 b$ & $15.16 \mathrm{a}$ & $10.92 b$ \\
\hline 866040 & $36.28 \mathrm{~b}$ & $6.04 \mathrm{~b}$ & $7.12 \mathrm{a}$ & $2.16 \mathrm{c}$ & $12.20 \mathrm{~b}$ & $11.08 \mathrm{~b}$ \\
\hline 866041 & $35.01 \mathrm{c}$ & $6.09 \mathrm{~b}$ & $6.56 a$ & $2.41 \mathrm{c}$ & 13.99a & $13.62 \mathrm{a}$ \\
\hline 866042 & $30.27 c$ & 7.09a & $6.25 b$ & $2.07 c$ & $13.32 \mathrm{~b}$ & $8.34 \mathrm{~d}$ \\
\hline 866043 & $31.21 \mathrm{c}$ & $7.22 \mathrm{a}$ & $6.59 a$ & $2.31 \mathrm{c}$ & $13.03 \mathrm{~b}$ & $12.18 b$ \\
\hline 866044 & $31.55 c$ & $6.71 \mathrm{a}$ & $6.78 a$ & $2.66 \mathrm{~b}$ & $13.35 b$ & $12.50 \mathrm{a}$ \\
\hline 870025 & $39.69 a$ & $6.71 \mathrm{a}$ & $6.75 a$ & $2.65 b$ & $11.72 \mathrm{c}$ & $10.10 \mathrm{c}$ \\
\hline 870081 & $40.45 a$ & $6.36 \mathrm{~b}$ & $6.03 b$ & $3.41 \mathrm{a}$ & $13.34 b$ & $9.47 \mathrm{c}$ \\
\hline 870085 & $38.64 b$ & $6.03 \mathrm{~b}$ & $6.63 a$ & $3.32 \mathrm{a}$ & $15.40 \mathrm{a}$ & $9.71 \mathrm{c}$ \\
\hline 870095 & $40.90 \mathrm{a}$ & $5.90 \mathrm{~b}$ & $5.92 b$ & $2.17 \mathrm{c}$ & $13.50 \mathrm{~b}$ & $9.34 \mathrm{c}$ \\
\hline 1F305 & $28.62 d$ & $5.62 b$ & $6.79 a$ & $2.02 \mathrm{c}$ & $11.55 \mathrm{c}$ & $6.13 \mathrm{~d}$ \\
\hline BRS 610 & $23.43 \mathrm{e}$ & 7.43a & $5.47 \mathrm{~b}$ & $2.26 c$ & $12.22 \mathrm{~b}$ & $8.06 \mathrm{~d}$ \\
\hline Volumax & $29.54 d$ & $6.49 b$ & $5.59 b$ & $2.67 b$ & $16.84 \mathrm{a}$ & $9.06 \mathrm{c}$ \\
\hline XBS60329 & $32.17 \mathrm{c}$ & $6.84 \mathrm{a}$ & $5.44 \mathrm{~b}$ & $2.42 \mathrm{c}$ & $16.55 \mathrm{a}$ & $7.29 \mathrm{~d}$ \\
\hline Mean & 34.68 & 6.48 & 6.43 & 2.52 & 13.52 & 10.23 \\
\hline CV (\%) & 6.20 & 8.29 & 6.87 & 15.58 & 12.26 & 15.20 \\
\hline
\end{tabular}

DM - dry matter; MM - mineral matter; CP - crude protein; EE - ether extract; NDIN - neutral detergent insoluble nitrogen; ADIN - acid detergent insoluble nitrogen; $\mathrm{NM}$ - natural matter; TN - total nitrogen; CV - coefficient of variation.

* Means followed by same letter in the column do not differ by the Scott-Knott test $(\alpha=0.05)$. 
observed DM values of 29.30 and $26.79 \mathrm{dag} / \mathrm{kg} \mathrm{NM}$ in the forage sorghum hybrids silage and 32.62 and $35.50 \mathrm{dag} / \mathrm{kg}$ NM in dual-purpose hybrid silage.

The concentration of MM was different $(\mathrm{P}<0.05)$ between silage hybrids, ranging from 5.62 to 7.43 , with an average of $6.48 \mathrm{dag} / \mathrm{kg}$ DM. These results were higher than those observed by Pedreira et al. (2003), which was 3.4 dag $/ \mathrm{kg}$ DM. The ether extract content showed variation from 1.73 to 3.52 with an average of $2.52 \mathrm{dag} / \mathrm{kg}$ DM.

The average concentration of CP was $6.47 \mathrm{dag} / \mathrm{kg} \mathrm{DM}$ in the silage hybrids, higher than those observed by Skonieski et al. (2010) and Cabral et al. (2003), of 6.10 and $5.53 \mathrm{dag} / \mathrm{kg}$ DM, respectively. For Neumann et al. (2002b), variations in the proportion of stems, leaves, and panicles of sorghum plants are the main responsible for variations in the protein content between different hybrids, since the appropriate fermentation profile minimizes losses of nutrients during the fermentation process.

Reflecting the fermentation process (Table 1), the concentrations of NDIN and ADIN observed in this study indicated that there was no significant loss of nitrogen, because they are within the ideal range, which is less than 12 dag/kg of total N (Roth \& Undersander, 1995). Cândido et al. (2002) found values of ADIN ranging from 6.32 and $12.66 \mathrm{dag} / \mathrm{kg}$ of total $\mathrm{N}$.

The concentrations of NFC showed differences $(\mathrm{P}>0.05)$ between the silage hybrids evaluated, but they were sufficient to ensure proper fermentation, since the soluble carbohydrates are the main substrate of lactic acid bacteria (Table 5). Hybrids 1F305, BRS 610, Volumax, and XBS60329 and had the lowest $(\mathrm{P}<0.05)$ levels of NFC and higher $(\mathrm{P}<0.05)$ NDFap levels. The hybrid $1 \mathrm{~F} 305$ is characterized as forage because of the small number of panicles which can probably explain the high content of fibrous carbohydrates. The likely explanation for the NFC values of the hybrids BRS 610, Volumax, and XBS60329 would be the absence of grains at harvest, due to bird attack.

For the ADFp concentration, no differences were found $(\mathrm{P}<0.05)$ with the lowest value observed in the hybrid 870031 and average of $34.11 \mathrm{dag} / \mathrm{kg}$ DM. Hemicellulose values ranged from 15.62 to $36.46 \mathrm{dag} / \mathrm{kg}$ DM. The results are similar to those observed by Skonieski et al. (2010). Neumann et al. (2002b), evaluating different sorghum hybrids, found an average of $32.69 \mathrm{dag} / \mathrm{kg}$ DM for ADF content.

Based on the data, it was found that the silages of sorghum hybrids evaluated in this study had sufficient levels of carbohydrates to ensure the lactic fermentation, which did not affect the bromatological characteristics as discussed.
Table 5 - Mean values of fibrous and non-fibrous carbohydrates of 25 sorghum hybrids silage

\begin{tabular}{|c|c|c|c|c|}
\hline \multirow[t]{2}{*}{ Hybrid } & NFC & NDFap & ADFp & HEM \\
\hline & \multicolumn{4}{|c|}{ dag/kg DM } \\
\hline 866005 & $24.86 \mathrm{c} *$ & $60.28 b$ & $40.48 a$ & $19.79 d$ \\
\hline 866019 & $36.38 \mathrm{a}$ & $48.76 \mathrm{e}$ & $33.14 \mathrm{a}$ & $15.62 d$ \\
\hline 866033 & $31.29 b$ & $53.87 \mathrm{c}$ & $33.94 \mathrm{a}$ & $19.93 d$ \\
\hline 866034 & $28.72 b$ & $55.95 c$ & $34.53 a$ & $21.42 c$ \\
\hline 866035 & 29.99b & $54.18 c$ & $34.48 a$ & $19.70 \mathrm{~d}$ \\
\hline 866036 & $31.87 b$ & $51.94 d$ & $31.80 \mathrm{~b}$ & $20.14 d$ \\
\hline 866037 & $28.30 \mathrm{~b}$ & $56.12 c$ & $33.53 a$ & $22.59 c$ \\
\hline 866040 & $33.41 \mathrm{a}$ & $51.27 \mathrm{~d}$ & $33.27 \mathrm{a}$ & $18.00 \mathrm{~d}$ \\
\hline 866041 & $32.61 \mathrm{a}$ & $52.33 d$ & $32.48 a$ & $19.85 d$ \\
\hline 866042 & 29.63b & $54.97 \mathrm{c}$ & $36.32 \mathrm{a}$ & $18.65 d$ \\
\hline 866043 & $27.23 c$ & $56.65 c$ & $35.81 \mathrm{a}$ & $20.85 c$ \\
\hline 866044 & $22.50 \mathrm{~d}$ & 61.36b & $32.98 a$ & $28.37 b$ \\
\hline 870025 & $23.36 \mathrm{~d}$ & $60.54 b$ & $35.25 a$ & $25.29 b$ \\
\hline 870031 & $35.30 \mathrm{a}$ & $48.48 \mathrm{e}$ & $26.32 c$ & $22.16 c$ \\
\hline 870035 & 22.99d & $61.42 b$ & $36.21 \mathrm{a}$ & $25.22 b$ \\
\hline 870041 & 20.93d & $61.35 b$ & $37.11 \mathrm{a}$ & $24.23 c$ \\
\hline 870051 & $25.99 c$ & $60.23 b$ & $36.37 \mathrm{a}$ & $23.86 c$ \\
\hline 870067 & $27.26 \mathrm{c}$ & $56.92 c$ & $35.54 \mathrm{a}$ & $21.38 c$ \\
\hline 870081 & $26.74 c$ & $57.46 \mathrm{c}$ & $35.13 \mathrm{a}$ & $22.33 c$ \\
\hline 870085 & $24.39 c$ & 59.64b & $30.43 b$ & $29.21 b$ \\
\hline 870095 & $30.58 b$ & $55.43 c$ & $34.72 \mathrm{a}$ & $20.71 c$ \\
\hline 1F305 & $22.14 d$ & $63.43 a$ & $35.20 \mathrm{a}$ & $28.24 b$ \\
\hline BRS 610 & $21.31 d$ & $63.53 a$ & $35.28 a$ & $28.25 b$ \\
\hline Volumax & $19.64 d$ & $65.61 \mathrm{a}$ & $29.15 b$ & $36.46 a$ \\
\hline XBS60329 & $23.02 d$ & $62.27 b$ & $33.32 \mathrm{a}$ & $28.96 b$ \\
\hline Mean & 27.22 & 57.36 & 34.11 & 23.25 \\
\hline CV (\%) & 10.05 & 4.20 & 7.34 & 11.48 \\
\hline
\end{tabular}

NFC - non-fiber carbohydrates; NDFap - neutral detergent fiber free of ash and protein; ADFp - acid detergent fiber free of protein; HEM - hemicelluloses; DM dry matter; CV - coefficient of variation.

* Means followed by same letter in the column do not differ by the Scott-Knot test $(\alpha=0.05)$

There are divergences of fermentation and bromatological characteristics of silages; however, they all have values within the standards which classify a quality silage.

\section{Conclusions}

All hybrids have the potential for silage, based on the fermentation and chemical composition. Through the divergence of the fermentative and bromatological characteristics, the silages made of hybrids 866019 and 870031 stand out, nutritionally, for presenting low content of fibrous carbohydrates, resulting in better fermented silage with greater nutritional value.

\section{References}

ARAÚJO, V.L.; RODRIGUEZ, N.M.; GONÇALVES, L.C. et al. Qualidade das silagens de três híbridos de sorgo ensilados em cinco diferentes estádios de maturação. Arquivo Brasileiro de Medicina Veterinária e Zootecnia, v.59, n.1, p.168-174, 2007.

BOLSEN, K.K.; LIN, C.; BRENT, B.E. Effect of silage additives on the microbial succession and fermentation process of alfalfa 
and corn silages. Journal of Dairy Science, v.75, n.11, p.3066-3083, 1992.

CABRAL, L.S.; VALADARES FILHO, S.C.; DETMANN, E. et al. Composição químico-bromatológica, produção de gás, digestibilidadein vitro da matéria seca e NDT estimado da silagem de sorgo com diferentes proporções de panículas. Revista Brasileira de Zootecnia, v.32, n.5, p.1250-1258, 2003.

CÂNDIDO, M.J.D.; OBEID, J.A.; PEREIRA, O.G. et al. Valor Nutritivo de silagens de híbridos de sorgo (Sorghum bicolor (L.) Moench) sob doses crescentes de adubação. Revista Brasileira de Zootecnia, v.31, n.1, p.20-29, 2002.

GOERING, H.K.; Van SOEST, P.J. Forage fiber analyses (apparatus, reagents, procedures and some applications). Washington, D.C.: USDA-ARS, 1975. 20p. (Agriculture Handbook, 379).

JOHNSON, R.A.; WICHERN, D.W. Applied multivariate statistical analysis. 3.ed. New Jersey: Prantice Hall, 1992. 642p.

KLEINSCHIMIT, D.H.; KUNG JR., L. A meta-analysis of the effects of Lactobacillus buchneri on the fermentation and aerobic stability of corn and grass and small-grains silages. Journal of Dairy Science, v.89, n.10, p.4005-4013, 2006.

KUNG JR., L.; RANJIT N.K. The effect of Lactobacillus buchneriand other additives on the fermentation and aerobic stability of barley silage. Journal of Dairy Science, v.84, p.1149-1155, 2001.

LICITRA, G.; HERNANDEZ, T.M.; VAN SOEST, P.J. Standardization of procedures for nitrogen fractionation of ruminant feeds. Animal Feed Science and Technology, v.57, n.4, p.347-358, 1996.

McDONALD, P.; HENDERSON, A.R.; HERON, S. The biochemistry of silage. 2.ed. Marlow: Chalcombe, 1991. 340p.

MERTENS, D.R. Gravimetric determination of amylase-treated neutral detergent fiber in feeds with refluxing in beaker or crucibles: collaborative study. Journal of AOAC International, v.85, p.1217-1240, 2002.

MOLINA, L.R.; GONÇALVES, L.C.; RODRIGUEZ, N.M. et al. Qualidade das silagens de seis genótipos de sorgo (Sorghum bicolor (L) Moench) em diferentes estádios de maturação. Arquivo Brasileiro de Medicina Veterinária e Zootecnia, v.54, n.2, p.159-168, 2002.

NEUMANN, M.; RESTLE, J.; ALVES FILHO, D.C. et al. Avaliação de diferentes híbridos de sorgo (Sorghum bicolor, L. Moench) quanto aos componentes da planta e silagens produzidas. Revista Brasileira de Zootecnia, v.31, n.1, p.302-312, 2002a (supl.).

NEUMANN, M.; RESTLE, J.; ALVES FILHO, D.C. et al. Avaliação do valor nutritivo de planta e da silagem de diferentes híbridos de sorgo (Sorghum bicolor, L. Moench). Revista Brasileira de Zootecnia, v.31, n.1, p.293-301, 2002b (supl.).

NEUMANN, M.; RESTLE, J.; BRONDANI, I.L. et al. Efeito do tamanho da partícula e do tipo de silo sobre o valor nutritivo da silagem de sorgo (Sorghum bicolor, L. Moench). Revista Brasileira de Milho e Sorgo, v.4, n.2, p.224-242, 2005.

PEDREIRA, M.S.; REIS, R.A.; BERCHIELLI, T.T. et al. Características agrônomicas e composição química de oito híbridos de sorgo (Sorghum bicolor (L.) Moench). Revista Brasileira de Zootecnia, v.32, n.5, p.1083-1092, 2003.

PELL, A.N.; SCHOFIELD, E.L.D.P. Computerized monitoring of gas production to measure forage digestion in vitro. Journal of Dairy Science, v.76, p.1063-1073, 1993.

RANJIT, N.K.; KUNG JR., L. The Effect of Lactobacillus buchneri, Lactobacillus plantarum, or a Chemical Preservative on the Fermentation and Aerobic Stability of Corn Silage. Journal of Dairy Science, v.83, n.3, p.526-535, 2000.

RIBEIRO, C.G.M.; GONÇALVES, L.C.; RODRIGUES, J.A.S. et al. Padrão de fermentação da silagem de cinco genótipos de sorgo. Arquivo Brasileiro de Medicina e Veterinária. Zootecnia, v.59, n.6, p.1531-1537, 2007.

ROCHA JR., V.R.; GONÇALVES, L.C.; RODRIGUES, J.A.S. et al. Avaliação de sete genótipos de sorgo (Sorghum bicolor (L.) Moench) para produção de silagem II. Padrão de fermentação. Arquivo Brasileiro de Medicina e Veterinária, v.52, n.5, p.512-520, 2000.

RODRIGUES, P.H.M.; SENATORE, A.L.; ANDRADE, S.J.T. et al. Efeitos da adição de inoculantes microbianos sobre a composição bromatológica e perfil fermentativo da silagem de sorgo produzida em silos experimentais. Revista Brasileira de Zootecnia, v.31, n.6, p.2373-2379, 2002.

ROTH, G.; UNDERSANDER, D. Silage additives. In: Corn silage production management and feeding. Madison: Madison American Society of Agronomy, 1995. p.27-29.

SANTOS, C.; FERREIRA, D.F.; BUENO FILHO, J.S.S. Novas alternativas de testes de agrupamento avaliadas por meio de simulação monte carlo. Ciência e Agrotecnologia, v.25, n.6, p.1382-1392, 2001.

SANTOS, E.M.; ZANINE, A.M.; DANTAS, P.A.S. et al. Composição bromatológica, perdas e perfil fermentativo de silagens de capim-elefante com níveis de jaca. Revista Brasileira de Saúde e Produção Animal, v.9, n.1, p.71-80, 2008.

SCOTT, A.J.; KNOTT, M. A cluster analysis method for grouping means in the analysis of variance. Biometrics, v.30, p.507-512, 1974.

SILVA, D.J.; QUEIROZ, A.C. Análise de alimentos: métodos químicos e biológicos. 3.ed. Viçosa, MG: UFV, 2002. 235p.

SILVA, T.C.; SANTOS, E.M.; AZEVEDO, J.A.G. et al. Agronomic divergence of sorghum hybrids for silage yield in the semiarid region of Paraiba. Revista Brasileira de Zootecnia, v.40, n.9, p.1886-1893, 2011.

SKONIESKI, F.R.; NORNBERG, J.L.; AZEVEDO, E.B. et al. Produção, caracterização nutricional e fermentativa de silagens de sorgo forrageiro e sorgo duplo propósito. Acta Scientiarum. Animal Sciences, v.32, n.1, p.27-32, 2010.

SNIFFEN, C.J.; O’CONNOR, J.D.; VAN SOEST, P.J. et al. A net carbohydrate and protein system for evaluating cattle diets: II - Carbohydrate and protein availability. Journal of Animal Science, v.70, n.12, p.3562-3577, 1992.

WOOLFORD, M.K. The silage fermentation. New York: Marcel Dekker, 1984. p.23-132. 